\title{
Relationship between renal tissues phospholipase A2 receptor and its serum antibody and clinical condition and prognosis of idiopathic membranous nephropathy: a meta-analysis
}

\author{
Dan Dong ${ }^{1 \dagger}$, Ting-ting Fan ${ }^{2,1 \dagger}$, Ying-ying Wang ${ }^{3}$, Lu Zhang ${ }^{1}$, Li Song ${ }^{1}$ and Li Zhang ${ }^{1 *}$ (I)
}

\begin{abstract}
Objective: To investigate the correlation of M-type phospholipase A2 receptor (PLA2R) expression and serum antiPLA2R antibody with the clinical parameters and prognosis of patients with idiopathic membranous nephropathy (IMN).

Methods: A literature search for relevant original articles published between January 2009 and October 2019 was conducted on domestic and foreign databases. RevMan 5.3 software was used for meta-analysis.

Results: Eighteen studies were included in this meta-analysis. There were 1235 anti-PLA2R antibody-positive and PLA2R-positive patients, and 407 serum anti-PLA2R antibody-negative and PLA2R-negative patients. Compared with negative group, patients in the serum PLA2R antibody -positive group had lower serum albumin $[S M D=-1.11,95 \%$ $\mathrm{Cl}(-1.82,-0.40), P<0.00001]$, higher age $[\mathrm{MD}=2.71,95 \% \mathrm{Cl}(1.94,3.48), P<0.00001]$, and lower estimated glomerular filtration rate (eGFR) $[\mathrm{MD}=-10.34,95 \% \mathrm{Cl}(-12.09,-8.60), P<0.00001]$; no significant between-group difference was observed with respect to $24-\mathrm{h}$ urine protein and serum creatinine. However, no significant difference was observed between renal tissues PLA2R -positive and -negative groups with respect to serum albumin, eGFR, serum creatinine, and 24-h urine protein. Remission rate in the serum anti-PLA2R antibody -positive group was lower than that in the -negative group $[\mathrm{OR}=0.41,95 \% \mathrm{Cl}(0.28,0.61), P<0.00001]$; however, no significant betweengroup difference in this respect was observed between the renal tissue PLA2R-positive and -negative groups. In the serum anti-PLA2R antibody -positive group, the higher titer subgroup had lower remission rate $[O R=0.19,95 \% \mathrm{Cl}$ $(0.07,0.55), P=0.002]$. No significant difference was observed between anti-PLA2R antibody -positive and -negative groups with respect to adverse events. Serum anti-PLA2R antibody titer did not affect the adverse event rate.
\end{abstract}

Conclusion: As compared to PLA2R, serum anti-PLA2R antibody is more closely related with IMN disease progression.

Keywords: PLA2R, Anti-PLA2R antibody, Idiopathic membranous nephropathy, Meta-analysis

\footnotetext{
* Correspondence: singer_zh@sina.com

${ }^{\dagger}$ Dan Dong and Ting-ting Fan contributed equally to this work.

'Department of Nephrology, First Hospital of Jilin University, 71 Xinmin

Street, Changchun, Jilin 130021, People's Republic of China

Full list of author information is available at the end of the article
}

(c) The Author(s). 2019 Open Access This article is distributed under the terms of the Creative Commons Attribution 4.0 International License (http://creativecommons.org/licenses/by/4.0/), which permits unrestricted use, distribution, and reproduction in any medium, provided you give appropriate credit to the original author(s) and the source, provide a link to the Creative Commons license, and indicate if changes were made. The Creative Commons Public Domain Dedication waiver (http://creativecommons.org/publicdomain/zero/1.0/) applies to the data made available in this article, unless otherwise stated. 


\section{Background}

Membranous nephropathy (MN) refers to a group of kidney diseases characterized by thickened glomerular basement membrane (GBM) and deposition of immune complexes on the GBM. According to the etiology, MN is classified into two types: idiopathic membranous nephropathy (IMN) and secondary membranous nephropathy (SMN) [1]. Studies have shown that about $40 \%$ of patients with IMN eventually develop end-stage renal disease (ESRD) [2]. Phospholipase A2 receptor (PLA2R) is a protein with a relative molecular weight of $180-200$ $\mathrm{kD}$. It is expressed on the membrane of human podocytes and belongs to the family of mannose receptors [3]. Till date, two subtypes of PLA2R have been found, namely M-type and N-type [4]. PLA2R is widely distributed in various organs of the human body, such as lung, kidney, and placenta [5]. In the kidney, M-type PLA2R is mainly expressed in the cytoplasm and membrane of the podocytes [6]. In 2009, Beck et al. detected the antiPLA2R antibody (anti-PLA2R Ab) in the serum of adult IMN patients and used it as a specific marker of IMN [7]. Since then, a series of studies [8-12] have demonstrated that renal expression of PLA2R and serum anti-PLA2R antibodies can be used for diagnosis, and prognostic assessment of patients with IMN. However, no systematic review has evaluated the relationship of PLA2R and serum antiPLA2R antibodies with IMN disease. In the present study, we performed a meta-analysis of data from relevant published clinical studies to evaluate this relationship.

\section{Methods}

\section{Eligibility criteria}

Studies that qualified the following criteria were included: (1) study type: cohort study; (2) Patients were diagnosed as idiopathic membranous nephropathy by renal biopsy; (3) The exposure factors: the study group was positive for serum PLA2R antibody or kidney tissues were PLA2R -positive, and the control group was serum PLA2R antibody -negative or renal tissues PLA2R -negative. (4) primary endpoint was complete remission (as defined in the included study) or partial remission (as defined in the included study) at the end of follow-up; secondary endpoint was adverse events such as renal injury, continuous proteinuria, progression to ESRD, disease palindromia, and death.

The exclusion criteria were: (1) patients with SMN; (2) duplicate publications; (3) literature reviews and animal experiments; (4) studies that had a follow-up time of $<6$ months.

\section{Data sources and search strategy}

Relevant studies published between January 2009 and October 2019 which investigated the relationship of PLA2R and its antibodies with the clinical parameters and prognosis of IMN were retrieved from Pubmed, EMBASE, MEDLINE, China Biomedical Literature Database, Chinese Journal Full-text Database, and Wanfang Database. We adopted joint search of free words and subject words. Chinese search terms included: glomerulonephritis, membranous nephropathy, M-type phospholipase A2, and cohort studies. English search terms included: "Glomerulonephritis, Membranous" [Mesh], "Receptors, Phospholipase A2" [Mesh], "Cohort Studies" [Mesh].

\section{Document retrieval process and results}

A total of 683 documents were retrieved on initial literature search. The title and abstracts were screened independently by two reviewers to eliminate irrelevant articles. Full text of the remaining documents was reviewed against the inclusion and exclusion criteria. In case of any disagreement between the two reviewers, the decision was taken by consensus or by a third reviewer.

Finally, only 18 relevant publications were selected for this meta-analysis $[8,10,11,13-27]$. These studies included 1235 PLA2R-positive and serum anti-PLA2R antibody-positive patients and 407 PLA2R-negative and serum PLA2R antibody-negative patients. A schematic illustration of literature search and results is shown in Fig. 1. The basic characteristics and results of quality assessment of the included studies are shown in Table 1. We measured serum creatinine, serum albumin, $24 \mathrm{~h}$ urine protein, eGFR to reflect the impairment of renal function in patients before treatment in anti-PLA2R antibody-positive, anti-PLA2R antibody-negative, kidney tissues PLA2R -positive and -negative groups. The remission rate and adverse prognosis was used to reflect the prognosis after treatment in anti-PLA2R antibody, renal tissue PLA2R -positive and -negative groups.

\section{Quality assessment}

The Newcastle-Ottawa Scale (NOS) for quality assessment of non-randomized controlled studies was used to evaluate the quality of the included studies, including aspects such as selection of subjects, comparability between groups and measurement of results. The full score is 9 , and a study received more than 5 was quality assessed. The quality assessment was performed independently by two reviewers; disagreements, if any, were resolved by consensus or by involvement of a third reviewer.

\section{Statistical analysis}

Meta-analysis was performed using RevMan 5.3 software. Mean difference (MD) and standardized mean difference (SMD) were used for continuous variables, while relative risk (RR) or odds ratio (OR) was used as effect size for categorical variables; 95\% confidence intervals were calculated for both. Heterogeneity among the 


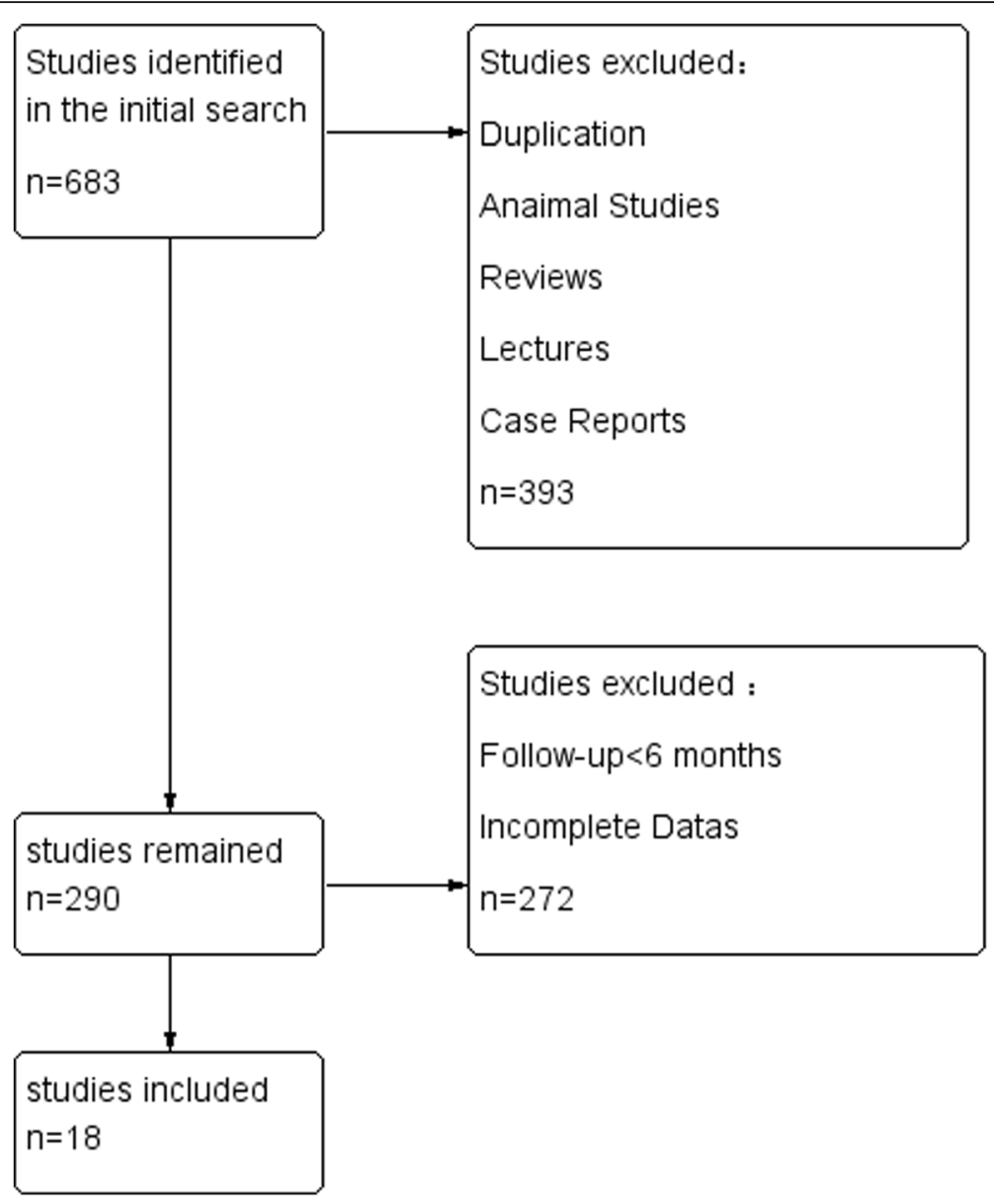

Fig. 1 Schematic illustration of the literature search and study selection criteria

included studies was assessed using $I^{2}$ statistic. In the absence of significant heterogeneity among the included studies $\left(P>0.1, I^{2}<50 \%\right)$, a fixed effect model was used for meta-analysis; in case of significant heterogeneity $\left(P<0.1, I^{2}>50 \%\right)$, a random effect model was used for meta-analysis. Publication bias was assessed by Egger's test and Begg's test using Stata13.0 software.

\section{Results}

\section{Comparison of serum albumin levels in anti- PLA2R antibody-positive, kidney tissues PLA2R -positive and -negative groups}

Eight studies had reported serum albumin levels in IMN patients disaggregated by serum anti-PLA2R antibodypositive $(n=748)$ and -negative groups $(n=268)$. Owing to significant heterogeneity among the studies $(P<$ 0.00001, $I^{2}=95 \%$ ), a random effect model was used for the meta-analysis. Serum albumin level in anti-PLA2R antibody-positive patients was significantly lower than that in anti-PLA2R antibody-negative patients [SMD = 1.11, 95\% CI (-1.82, - 0.40), $P=0.002$ ] (Fig. 2).
Three studies had reported serum albumin levels in IMN patients disaggregated by renal tissue PLA2Rpositive and -negative groups. Owing to the lack of significant heterogeneity among the studies $\left(P=0.95, I^{2}=\right.$ $0 \%$ ), the fixed effect model was used for the analysis. The results showed no significant between-group difference with respect to serum albumin levels $[M D=-1.50$, $95 \%$ CI $(-4.03,-1.02), P=0.24$ ] (Fig. 3).

\section{Comparison of age between renal tissue PLA2R-positive,} anti-PLA2R antibody-positive and -negative groups

Eight studies reported the age of IMN patients disaggregated by anti-PLA2R antibody-positive $(n=596)$ and -negative $(n=205)$ groups. Owing to the lack of significant heterogeneity $\left(P=0.23, I^{2}=25 \%\right)$, the fixed effect model was used for analysis. The results showed that age of patients in the anti-PLA2R antibody-positive group was significantly higher than that in the antiPLA2R antibody-negative group $[\mathrm{MD}=2.71,95 \% \mathrm{CI}$ (1.94, 3.48), $P<0.00001$ ] (Fig. 4).

Three studies reported the age of IMN patients disaggregated by renal tissue PLA2R-positive and -negative 
Table 1 Baseline characteristics of cohorts in all included studies

\begin{tabular}{|c|c|c|c|c|c|c|}
\hline Studies & area & PLA2R/anti-PLA2R (+/-) & Testing location & Testing Method & Follow-up (month) & NOS scores \\
\hline Wang LJ 2016 & China & $40 / 16$ & renal tissues & IFA & 12 & 8 \\
\hline Liu H 2016 & China & $56 / 11$ & renal tissues & IFA & $>12$ & 8 \\
\hline Pourcine F 2017 & France & $69 / 8$ & serum & ELISA & 168 & 8 \\
\hline Ramachandran R 2016 & India & $94 / 20$ & serum & ELISA & 12 & 7 \\
\hline Beck LH 2011 & Canada & $25 / 10$ & serum & WB & 24 & 8 \\
\hline Wang J 2017 & China & $78 / 13$ & renal tissues & IFA & 15 & 7 \\
\hline Bech AP 2014 & Hollan & $34 / 14$ & serum & ELISA & 60 & 8 \\
\hline Zhou GY 2017 & China & $40 / 16$ & serum & ELISA & 6 & 7 \\
\hline Qin W 2011 & China & $49 / 11$ & serum & ELISA & $>12$ & 5 \\
\hline Oh YJ 2013 & Korea & $69 / 31$ & serum & WB & 30 & 8 \\
\hline Kim YG2015 & Korea & $41 / 52$ & serum & ELISA & 24 & 7 \\
\hline Ruggenenti P 2015 & France & $81 / 20$ & serum & ELISA & 12 & 6 \\
\hline Timmermans SA 2015 & Hollan & $65 / 8$ & serum & IFA & 11.3 & 6 \\
\hline Hofstra JM 2012 & Europe & $82 / 28$ & serum & IFA、ELISA & 54 & 6 \\
\hline Liang Y 2017 & China & $42 / 37^{*}$ & serum & ELISA & 12 & 7 \\
\hline Huang J 2017 & China & 29/11 & serum & IFA & $>12$ & 7 \\
\hline Zhang D 2018 & China & $164 / 28$ & serum & ELISA & $>13.6$ & 7 \\
\hline Li Q 2018 & China & $177 / 73$ & serum & ELISA & $>6$ & 7 \\
\hline
\end{tabular}

Note:IFA indirect immunofluorescence assay, ELISA enzyme-linked immunosorbent assay, WB Western blotting, ${ }^{*}$ High titer/Low titer

groups. Owing to the lack of significant heterogeneity among the studies $\left(P=0.93, I^{2}=0 \%\right)$, the fixed effect model was used. The results showed no significant difference between the age of patients in the two groups $[\mathrm{MD}=-1.35,95 \% \mathrm{CI}(-6.51,3.80), P=0.61]$ (Fig. 5).

\section{Comparison of serum creatinine level between anti- PLA2R antibody -positive and -negative groups}

Seven studies reported serum creatinine level in IMN patients disaggregated by serum anti-PLA2R antibody -positive $(n=610)$ and -negative $(n=230)$ groups. Owing to the lack of significant heterogeneity $\left(P<0.0001, I^{2}=\right.$ $90 \%)$, the fixed-effect model was used for analysis. There was no significant difference between the two groups $[\mathrm{SMD}=0.43,95 \% \mathrm{CI}(-0.10,0.97), P=0.11]$ (Fig. 6).
Comparison of estimated glomerular filtration rate between anti-PLA2R antibody -positive and -negative groups

Five studies reported the estimated glomerular filtration rate (eGFR) of IMN patients disaggregated by serum anti-PLA2R antibody -positive $(n=381)$ and -negative $(n=149)$ groups. Owing to the lack of significant heterogeneity $\left(P=0.17, I^{2}=38 \%\right)$, the fixed effect model was used. eGFR of patients in the serum anti-PLA2R antibody -positive group was significantly lower than that in the serum anti-PLA2R antibody-negative group [MD = 10.34, 95\% CI(-12.09, -8.60$), P<0.00001]$ (Fig. 7).

\section{Comparison of 24-h urine protein between serum anti-} PLA2R antibody -positive and -negative groups

Four studies had reported 24-h urinary protein of IMN patients disaggregated by serum anti-PLA2R antibody

\begin{tabular}{|c|c|c|c|c|c|c|c|c|c|c|c|c|}
\hline Studv or Subgroup & $\begin{array}{l}\text { anti-P } \\
\text { Mean }\end{array}$ & $\begin{array}{l}\text { LA2R A } \\
\text { SD }\end{array}$ & $\begin{array}{l}b+ \\
\text { Total }\end{array}$ & $\begin{array}{l}\text { anti-P } \\
\text { Mean }\end{array}$ & $\begin{array}{l}\text { LA2R A } \\
\text { SD }\end{array}$ & $\begin{array}{l}\text { botal } \\
\text { Total }\end{array}$ & Weight & $\begin{array}{l}\text { Std. Mean Difference } \\
\text { IV, Random, } 95 \% \mathrm{Cl}\end{array}$ & Year & $\begin{array}{l}\text { Std. Mean } \\
\text { IV, Rando] }\end{array}$ & $\begin{array}{l}\text { Difference } \\
\text { om, } 95 \% \mathrm{Cl}\end{array}$ & \\
\hline Hofstra JM 2012 & 23 & 5.5 & 82 & 21.9 & 7.5 & 28 & $12.8 \%$ & $0.18[-0.25,0.61]$ & 2012 & & & \\
\hline Oh YJ 2013 & 2.5 & 0.6 & 69 & 3.1 & 0.9 & 31 & $12.7 \%$ & $-0.84[-1.28,-0.40]$ & 2013 & & & \\
\hline Ruggenenti P 2015 & 1.96 & 0.57 & 81 & 2.69 & 0.5 & 20 & $12.5 \%$ & $-1.30[-1.82,-0.78]$ & 2015 & & & \\
\hline Kim YG2015 & 2.6 & 0.09 & 41 & 3.06 & 0.1 & 52 & $11.4 \%$ & $-4.77[-5.58,-3.95]$ & 2015 & 4 & & \\
\hline Ramachandran R 2016 & 2.28 & 0.65 & 94 & 2.35 & 0.64 & 20 & $12.6 \%$ & $-0.11[-0.59,0.38]$ & 2016 & & & \\
\hline Zhou GY 2017 & 21.66 & 4.78 & 40 & 29.66 & 5.78 & 16 & $12.0 \%$ & $-1.55[-2.21,-0.90]$ & 2017 & & & \\
\hline Zhang D 2018 & 25.89 & 5.46 & 164 & 28.53 & 6.56 & 28 & $12.8 \%$ & $-0.47[-0.87,-0.06]$ & 2018 & & & \\
\hline Li Q 2018 & 22.21 & 4.6 & 177 & 24.22 & 4.28 & 73 & $13.1 \%$ & $-0.44[-0.72,-0.17]$ & 2018 & & & \\
\hline Total $(95 \% \mathrm{Cl})$ & & & 748 & & & 268 & $100.0 \%$ & $-1.11[-1.82,-0.40]$ & & & & \\
\hline \multicolumn{10}{|c|}{$\begin{array}{l}\text { Heterogeneity: } \text { Tau }^{2}=0.97 ; \mathrm{Chi}^{2}=135.06, \mathrm{df}=7(\mathrm{P}<0.00001) ; I^{2}=95 \% \\
\text { Test for overall effect: } Z=3.07(P=0.002)\end{array}$} & $\begin{array}{ccc}-2 & -1 & 0 \\
\text { Favours [experimental] }\end{array}$ & $\begin{array}{cc}0 & 1 \\
& \text { Favours [control] }\end{array}$ & 2 \\
\hline
\end{tabular}




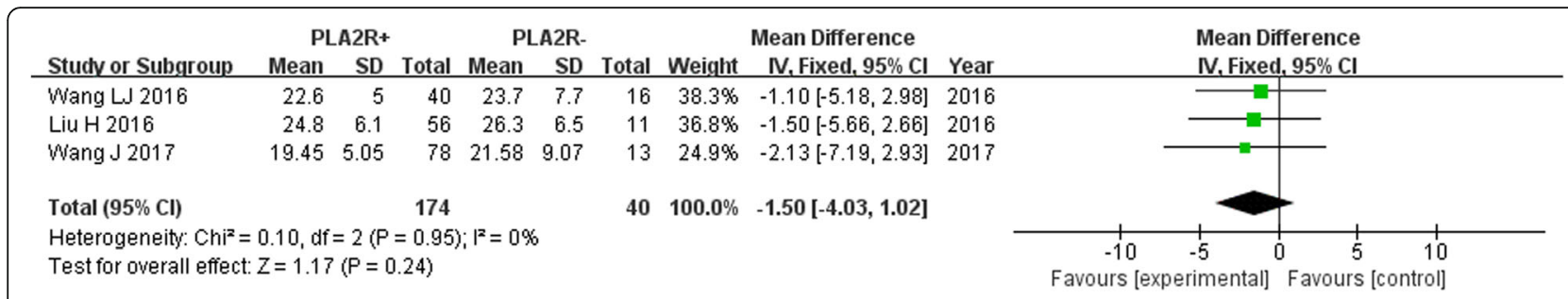

Fig. 3 Meta-analysis of serum albumin levels: renal tissue PLA2R-positive group versus -negative group

-positive $(n=460)$ and -negative $(n=131)$ groups. Owing to significant heterogeneity among the studies $(P=0.06$, $\left.I^{2}=59 \%\right)$, the random effect model was used for analysis. The results showed no significant between-group difference in this respect $[S M D=0.27,95 \%$ CI $(-0.07,0.61)$, $P=0.12]$ (Fig. 8).

\section{Comparison of clinical parameters between renal tissue PLA2R -positive and -negative groups}

We also performed a meta-analysis of serum creatinine, 24-h urine protein, and eGFR in the renal tissue PLA2Rpositive and -negative groups. The $95 \%$ confidence interval included 0 , and $P>0.05$. No significant between-group differences were observed in this respect (Table 2).

\section{Comparison of remission rate between anti-PLA2R antibody, renal tissue PLA2R -positive and -negative groups}

Ten studies reported the remission rate of IMN patients disaggregated by serum anti-PLA2R antibody -positive $(n=675)$ and -negative $(n=226)$ groups. Owing to the lack of significant heterogeneity among the studies $(P=$ $\left.0.23, I^{2}=23 \%\right)$, the fixed effect model was used. The results of the meta-analysis were $z=4.47, P<0.00001$, and the difference was statistically significant (Fig. 9). The combined effect of OR was $0.41,95 \% \mathrm{CI}$ : $(0.28,0.61)$. When $\mathrm{OR}=1.00$, it indicated that serum anti-PLA2R antibody -positive status was not related to the rate of remission in IMN patients. When $\mathrm{OR}>1.00$, it indicated that anti-PLA2R antibody -positive status was related to the remission rate of IMN patients, and the remission rate was high for these patients. When $\mathrm{OR}<1.00$, it indicated that anti-PLA2R antibody -positive status was related to the remission rate, but had low remission rate. When OR was more distant from 1.00, it indicated greater strength of correlation. If the invalid value (1.00) is within $95 \% \mathrm{CI}$, it indicated the lack of statistical significance. In this analysis, the invalid value was not within 95\% CI, but was farther away from the original value, which suggested that the expression of serum anti-PLA2R antibody reduced the remission rate of IMN patients with increase in the strength of correlation.

Three studies reported the complete remission rate of IMN patients disaggregated by renal tissue PLA2R -positive and -negative groups. Owing to the lack of significant heterogeneity among the studies $\left(P=0.002, I^{2}=\right.$ $84 \%)$, the fixed effect model was used. The results showed no significant difference in the remission rate between the two groups $[\mathrm{OR}=0.42,95 \%$ CI $(0.02,8.02)$, $P=0.56$ ] (Fig. 10).

\section{Relationship of remission rate and titre levels of serum anti-PLA2R antibody}

Five studies reported remission rates of serum antiPLA2R antibody-positive IMN patients disaggregated by high-titer $(n=183)$ and low-titer $(n=120)$ groups. Owing to significant heterogeneity among the studies $\left(P=0.02, I^{2}=66 \%\right)$, the random effect model was used. The results of the meta-analysis were $z=3.08, P=$ $0.002<0.05$, and the difference was statistically significant (Fig. 11). The combined effects were $\mathrm{OR}=0.19$ (95\% CI: 0.07, 0.55). The invalid value was not within

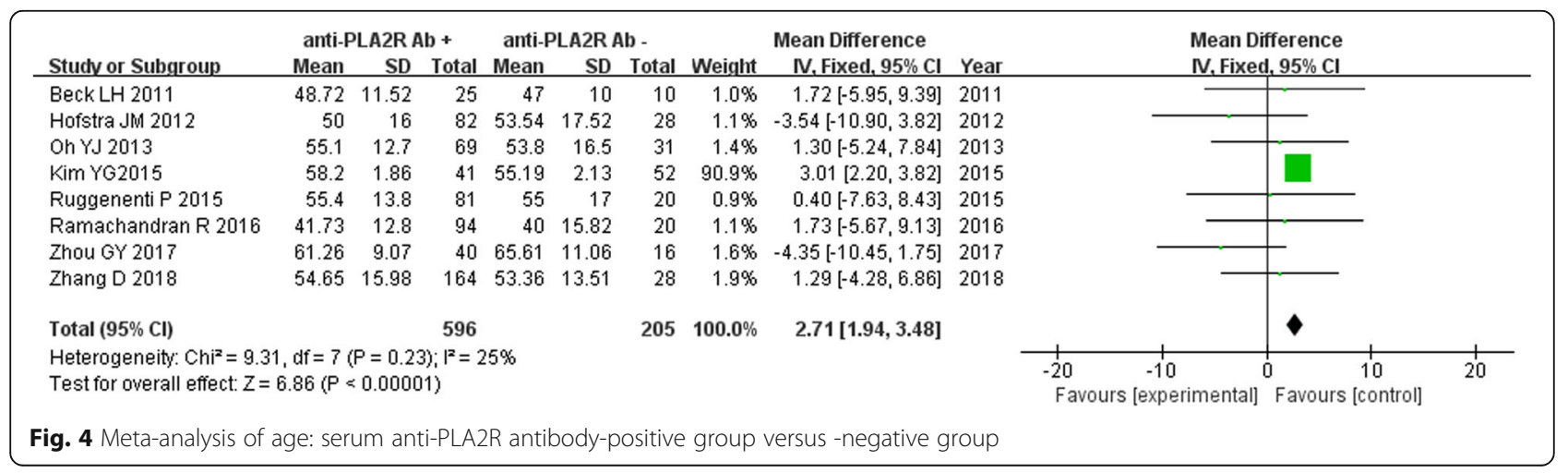




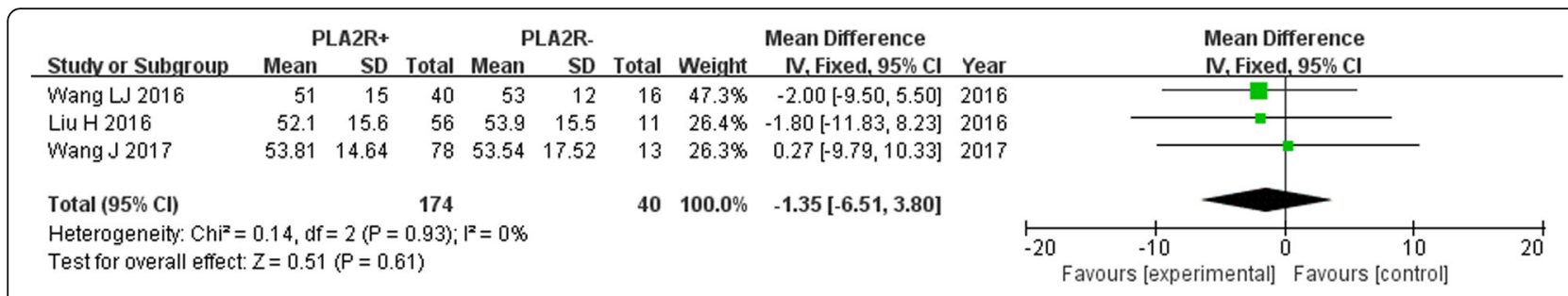

Fig. 5 Meta-analysis of age: renal tissue PLA2R-positive group versus -negative group

the $95 \% \mathrm{CI}$, and the difference was statistically significant. Away from 1.00, suggesting that the high expression of serum anti-PLA2R antibody reduced the remission rate of IMN patients and the strength of correlation was greater.

\section{Comparison of adverse prognosis of IMN patients with} serum anti-PLA2R antibody positive and negative groups Seven studies reported the occurrence of adverse prognosis in 590 IMN patients with serum anti-PLA2R antibody positive $(n=478)$ and negative $(n=112)$ groups. Owing to the lack of significant heterogeneity among the studies $\left(P=0.79, I^{2}=0 \%\right)$, the fixed effect model was used. The meta-analysis results showed that $z=1.11$, $P=0.27>0.05$, and the difference was not statistically significant (Fig. 12). The combined effect was $\mathrm{OR}=1.36$, 95\% CI: $0.79,2.34$, and the invalid value was 1.00 within 95\% CI. The study suggested that there was no significant difference in the incidence of poor prognosis between the two groups of IMN patients.

\section{Comparison of adverse prognosis in the high-titer and low-titer anti-PLA2R antibody -positive subgroups}

Three studies reported the occurrence of adverse prognosis in anti-PLA2R antibody-positive IMN patients disaggregated by high-titer $(n=96)$ and low-titer $(n=95)$ subgroups. Owing to significant heterogeneity among the studies $\left(P=0.23, I^{2}=33 \%\right)$, the random effect was used. The results of meta-analysis were $\mathrm{z}=1.46, P=$ $0.14>0.05$, and the difference was not statistically significant (Fig. 13). The combined effects were OR 1.66,
95\% CI: 0.84, 3.29, and the invalid value was within 95\% CI. There was no significant difference in the incidence of adverse prognosis between the two sub-groups of anti-PLA2R antibody positive IMN patients.

\section{Assessment of publication bias}

We also assessed publication bias using Egger's test and Begg's Test with Stata 13.0 software (Table 3). The results showed that for the comparison of serum antiPLA2R antibody -positive and -negative groups, except for the age, all other factors were not statistically significant $(P>0.05)$; this suggested the absence of publication bias. For the comparison of serum anti-PLA2R antibody high- and low -titer subgroups, except for the remission rate, all other factors were not statistically significant $(P>0.05)$, which suggested that there was no publication bias. Comparison of serum albumin in serum antiPLA2R antibody -positive and -negative groups and comparison of the remission rate in serum anti-PLA2R antibody high- and low -titer subgroups were associated with $P$ value $<0.05$, which was indicative of the presence of publication bias.

\section{Discussion}

IMN is the most common pathological type of nephrotic syndrome in the elderly people [28], and it is one of the major underlying causes of ESRD [2]. With the progress in understanding of its pathogenesis, IMN is now recognized as an autoimmune disease [29]. The clinical diagnosis of IMN mainly relies on renal biopsy. The patient's condition and treatment effect are evaluated mainly by

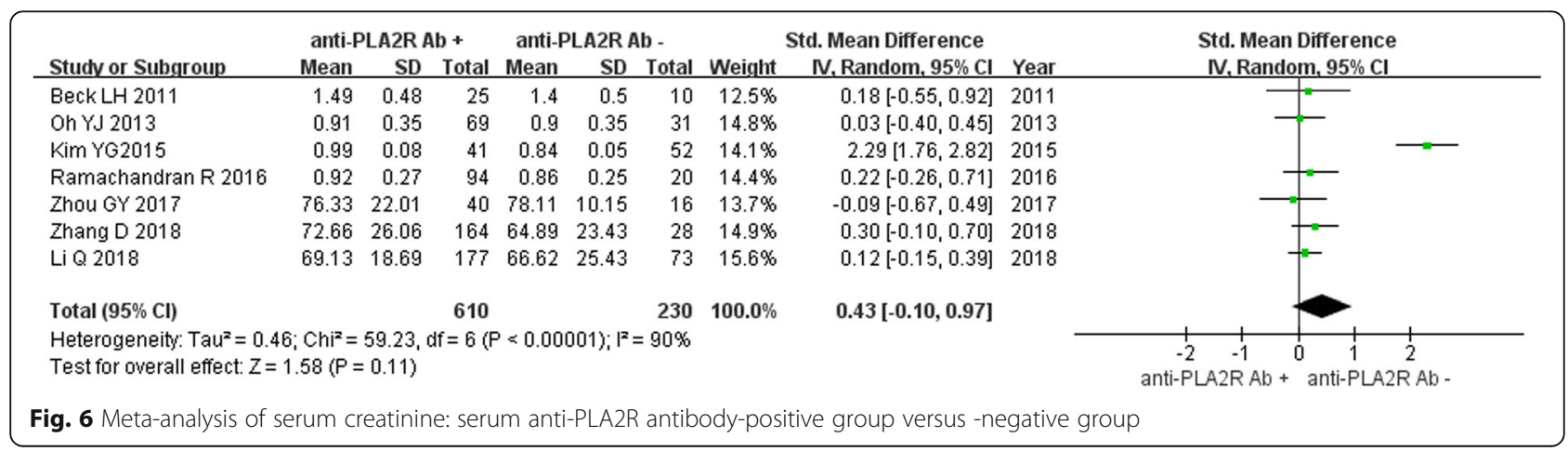




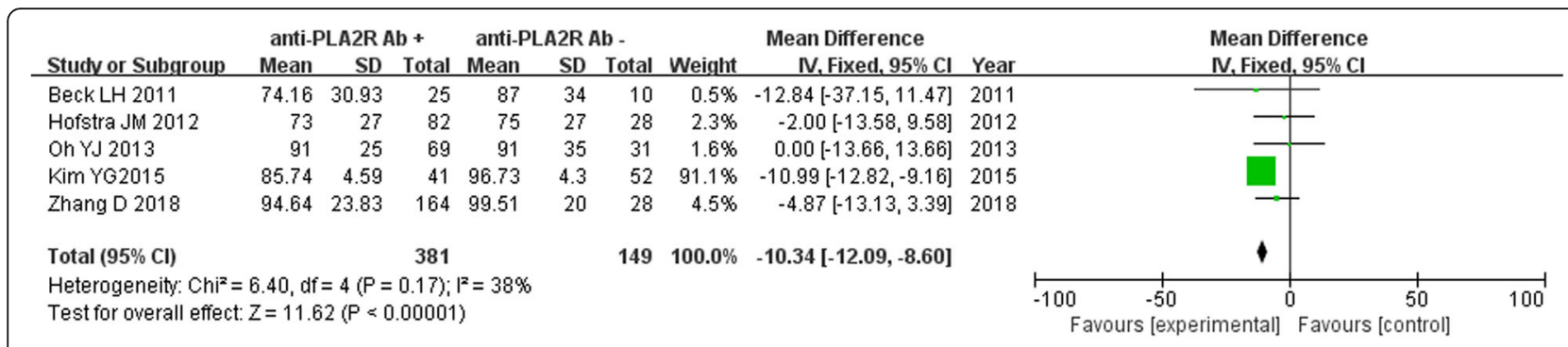

Fig. 7 Meta-analysis of eGFR: serum anti-PLA2R antibody-positive group versus -negative group

monitoring 24-h urine protein, serum albumin, and serum creatinine [30]. Although renal biopsy is the gold standard for diagnosis of IMN, the procedure is associated with a risk of bleeding and infection. Identification of relatively safe and convenient method for diagnosis and prognostic assessment of patients with IMN will confer a considerable leverage to nephrologists. As early as 2002, Debiec et al. [31] found that neutral endopeptidase is the target antigen of podocytes in membranous nephropathy; however, it is found in only a small proportion of IMN patients. A large number of studies have demonstrated the diagnostic relevance of serum antiPLA2R antibodies in the context of IMN. In a metaanalysis [32], serum anti-PLA2R antibodies exhibited $68 \%$ sensitivity and $97 \%$ specificity for the diagnosis of IMN. A large body of evidence supports the relationship between PLA2R and the clinical course and prognosis of IMN. Wang J et al. [11] followed up 91 patients with pathologically confirmed IMN for 15 months. These included 78 serum anti-PLA2R antibody -positive patients and 13 serum anti-PLA2R antibody -negative patients; all patients were administered immunosuppressive therapy [glucocorticoid plus cyclophosphamide $(n=45)$; glucocorticoid plus calcineurin inhibitors $(n=46)]$. They found that in the third and sixth month of treatment, the remission rate of serum anti-PLA2R antibody -positive patients was lower than that of -negative patients; in addition, serum anti-PLA2R antibody -negative patients showed a faster response to immunosuppressive therapy as compared to serum anti-PLA2R antibody -positive patients. Pang et al [33] found a positive correlation of serum anti-PLA2R antibody levels with serum albumin, serum creatinine, eGFR, and urinary protein. The glomerular PLA2R deposition intensity showed a weak correlation with proteinuria. They suggested that serum anti-PLA2R antibody more closely reflects the disease activity and renal function as compared to PLA2R. In a study by Wei et al. [34], serum anti-PLA2R antibody and renal tissue PLA2R positivity rates in IMN patients were 82.3 and $85.8 \%$, respectively. Serum anti-PLA2R antibody titers were significantly associated with proteinuria in the first 20 months of follow-up. Moreover, changes in serum anti-PLA2R antibody levels preceded the changes in proteinuria. They concluded that serum PLA2R antibody titer, but not renal expression of PLA2R, reflects the prognosis of IMN. Studies [35] have also shown that the effect of immunosuppressive therapy on anti-PLA2R antibody titer in the first 3 months of treatment is a sensitive and specific predictor of therapeutic response at 6th and 9th month of treatment in patients with IMN; further, decrease in antibody at the 6th month was also shown to predict the response at the 12th month. These studies further suggest that serum anti-PLA2R antibodies and PLA2R are closely related to the disease activity and prognosis of IMN.

The present meta-analysis addresses a gap in contemporary literature in that this is the first meta-analysis of the clinical relevance and prognostic value of serum anti-PLA2R antibodies and renal expression of PLA2R in patients with IMN. The results showed that serum albumin and eGFR in serum anti-PLA2R antibody -positive group of IMN patients were lower than those in the serum anti-PLA2R antibody-negative group, while age and serum creatinine levels were higher in the former group. No significant between-group difference was observed with respect to 24 -h urine protein. No significant

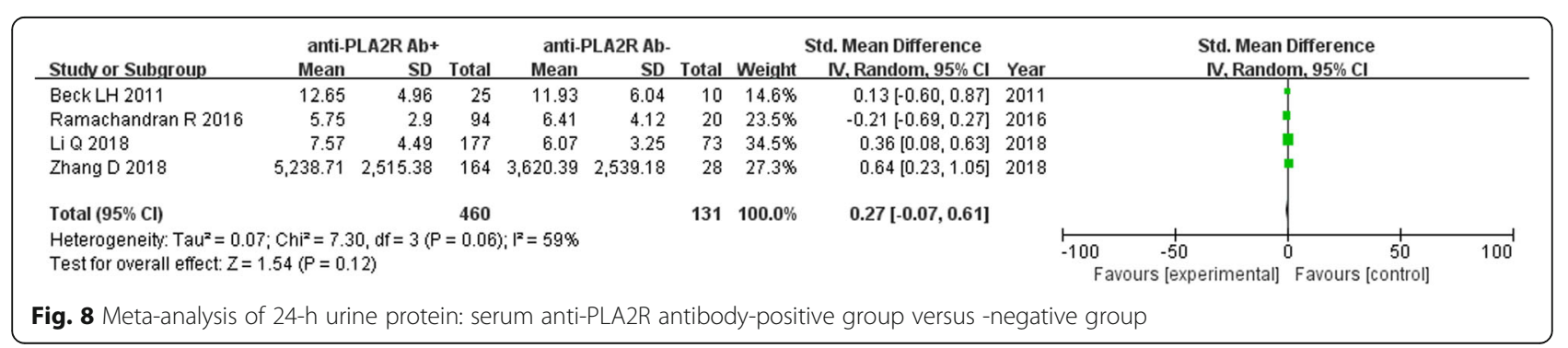


Table 2 Comparison of clinical parameters in renal tissues PLA2R-positive and -negative groups

\begin{tabular}{|c|c|c|c|c|c|c|c|c|c|c|}
\hline Parameter & Included studies & Model & $P L A 2 R+(n)$ & PLA2R-(n) & P\# & 12 & MD/SMD & $95 \% \mathrm{Cl}$ & z & $P^{*}$ \\
\hline eGFR & 2 & Fixed & 96 & 27 & 0.45 & $0 \%$ & 8.08 & $-1.53,17.70$ & 1.65 & 0.1 \\
\hline Serum creatinine & 2 & Random & 96 & 27 & 0.88 & $0 \%$ & -6.33 & $-16.45,3.80$ & 1.22 & 0.22 \\
\hline 24-hour urine protein & 2 & Random & 96 & 27 & 0.58 & $0 \%$ & 0.7 & $-0.74,2.13$ & 0.95 & 0.34 \\
\hline
\end{tabular}

$\# P$ value for heterogeneity test; $* P$ value for statistical significance.

$M D$ mean difference, SMD standardized mean difference, $\mathrm{Cl}$ confidence interval, eGFR estimated glomerular filtration rate

difference was observed between renal tissue PLA2R -positive and -negative groups with respect to age, 24-h urine protein, eGFR, or serum albumin. In summary, serum anti-PLA2R antibody expression may correlate with the severity of IMN. The endpoints were sparsely including the serum albumin levels (Fig. 3), 24-h urine protein (Fig. 3) and the remission rate (Fig. 10) in our study, but they are 3 important index during the treatment of membranous nephropathy, which are used to reflect the severity of membranous nephropathy. Age (Fig. 5) and adverse prognosis (Fig. 13) are 2 established prognostic factors in membranous nephropathy. So, the above indicators are essential in our meta-analysis. Our findings are consistent with those of several previous clinical studies [33, 34], although some findings were different from other studies [33]. These may be attributable to differences with respect to the nature of research, objective, measurement technology used and clinical treatment methods. Due to inconsistent clinical data included in the study, we were unable to compare other factors such as blood lipids and blood pressure. For prognostic assessment of IMN patients, we found that serum anti-PLA2R antibody expression correlated with the remission rate of IMN patients, as the remission rate in the serum anti-PLA2R antibody-positive group was lower than that in the -negative group. Serum anti-PLA2R antibody expression levels were also associated with remission rates The high-titer group had a lower response rate; however, the expression of PLA2R in the renal tissue and the expression level were not significantly associated with remission rate. We did not conduct a meta-analysis about the relationship between the expression of PLA2R in the renal tissue and the poor prognosis of IMN, because only one study was included. However, for the reverse prognosis of IMN patients we did not conduct a metaanalysis because only one study of PLA2R in the renal tissue was included. In addition, the expression of serum anti-PLA2R antibody has no correlation to poor prognosis of IMN. In addition, serum anti-PLA2R antibody expression and the level of expression and IMN patients have no significant statistical significance. Although our metaanalysis results are different from the above results, serum anti-PLA2R antibody expression still has certain guiding significance for monitoring the severity of IMN patients and judging the prognosis. Meta-analysis aims to increase the credibility of conclusions and solve the inconsistency of research results by increasing the sample content. Although some endpoints were sparsely and inconsistently reported by some primary studies, meta-analysis can still increase the credibility of the original literatures and provide more powerful evidence for clinical work. Some limitations of our meta-analysis need to be considered while interpreting our results: (1) only 3 studies had reported data on PLA2R expression in renal tissues, and the sample size of patients was relatively small, which may have affected our results. (2) Lack of relevant data from individual studies may reflect the potential impact of publication bias. (3) The results of individual studies are liable to be influenced by the research subjects, measurement methods, and treatment modalities. Due

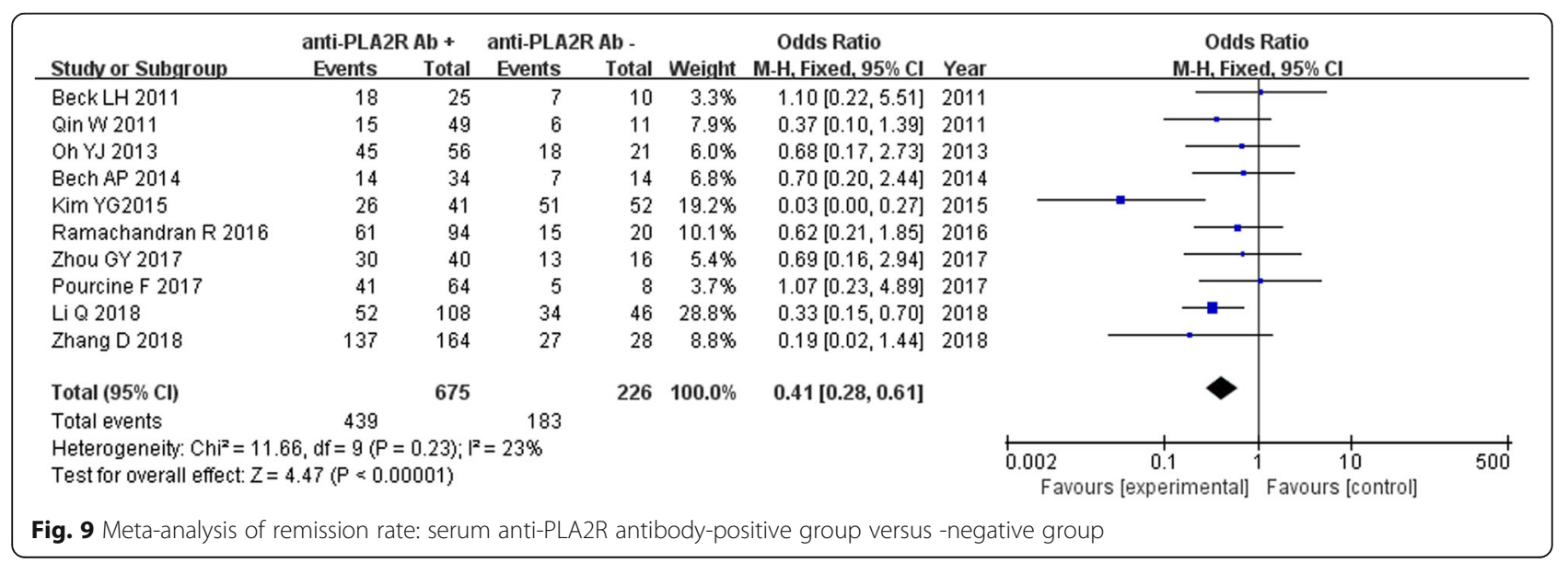




\begin{tabular}{|c|c|c|c|c|c|c|c|c|c|c|}
\hline Studv or Subgroup & $\begin{array}{l}\text { PLA2R } \\
\text { Events }\end{array}$ & Total & $\begin{array}{l}\text { PLA2 } \\
\text { Events }\end{array}$ & Total & Weight & $\begin{array}{l}\text { Odds Ratio } \\
\text { M-H, Random, } 95 \% \mathrm{Cl}\end{array}$ & Year & $\begin{array}{r}\text { Odds } \\
\text { M-H, Rando }\end{array}$ & $\begin{array}{l}\text { Ratio } \\
\text { om, } 95 \% \mathrm{Cl}\end{array}$ & \\
\hline Wang LJ 2016 & 25 & 40 & 16 & 16 & $29.2 \%$ & $0.05[0.00,0.89]$ & 2016 & 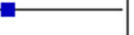 & & \\
\hline Liu H 2016 & 47 & 56 & 6 & 11 & $37.2 \%$ & $4.35[1.09,17.38]$ & 2016 & & & \\
\hline Wang J 2017 & 55 & 78 & 12 & 13 & $33.6 \%$ & $0.20[0.02,1.62]$ & 2017 & & - & \\
\hline Total $(95 \% \mathrm{Cl})$ & & 174 & & 40 & $100.0 \%$ & $0.42[0.02,8.02]$ & & & & \\
\hline Total events & 127 & & 34 & & & & & & & \\
\hline \multicolumn{7}{|c|}{$\begin{array}{l}\text { Heterogeneity: } \operatorname{Tau}^{2}=5.61 ; \mathrm{Chi}^{2}=12.34, \mathrm{df}=2(\mathrm{P}=0.002) ; \mathrm{I}^{2}=84 \% \\
\text { Test for overall effect: } Z=0.58(\mathrm{P}=0.56)\end{array}$} & 0.002 & $\begin{array}{l}0.1 \\
\text { PLA2R+ }\end{array}$ & $\begin{array}{c}10 \\
\text { PLA2R- }\end{array}$ & 500 \\
\hline
\end{tabular}

\begin{tabular}{|c|c|c|c|c|c|c|c|c|c|c|}
\hline Studv or Subgroup & $\begin{array}{l}\text { 'High' tit } \\
\text { Events }\end{array}$ & $\begin{array}{l}\text { ter } \\
\text { Total } \\
\end{array}$ & $\begin{array}{l}\text { 'Low' tit } \\
\text { Events }\end{array}$ & $\begin{array}{l}\text { ter } \\
\text { Total }\end{array}$ & Weight & $\begin{array}{c}\text { Odds Ratio } \\
\text { M-H. Random. } 95 \% \mathrm{Cl}\end{array}$ & Year & $\begin{array}{r}\text { Odds } \\
\text { M-H, Rands }\end{array}$ & $\begin{array}{l}\text { Ratio } \\
\text { lom, } 95 \% \mathrm{Cl}\end{array}$ & \\
\hline Hofstra JM 2012 & 31 & 52 & 18 & 27 & $24.3 \%$ & $0.74[0.28,1.95]$ & 2012 & $\rightarrow$ & 7 & \\
\hline Kim YG2015 & 8 & 20 & 18 & 21 & $18.7 \%$ & $0.11[0.02,0.51]$ & 2015 & & & \\
\hline Timmermans SA 2015 & 28 & 44 & 17 & 21 & $21.4 \%$ & $0.41[0.12,1.44]$ & 2015 & & & \\
\hline Liang $Y 2017$ & 25 & 42 & 35 & 37 & $18.3 \%$ & $0.08[0.02,0.40]$ & 2017 & & & \\
\hline Huang J 2017 & 4 & 25 & 11 & 14 & $17.3 \%$ & $0.05[0.01,0.27]$ & 2017 & & & \\
\hline Total $(95 \% \mathrm{Cl})$ & & 183 & & 120 & $100.0 \%$ & $0.19[0.07,0.55]$ & & & & \\
\hline Total events & 96 & & 99 & & & & & & & \\
\hline \multicolumn{8}{|c|}{$\begin{array}{l}\text { Heterogeneity: } \mathrm{Tau}^{2}=0.92 ; \mathrm{Chi}^{2}=11.80, \mathrm{df}=4(\mathrm{P}=0.02) ; \mathrm{I}^{2}=66 \% \\
\text { Test for overall effect: } Z=3.08(P=0.002)\end{array}$} & $\begin{array}{cc}0.002 & 0.1 \\
\text { Favours [experimental] }\end{array}$ & $\begin{array}{l}11 \\
\text { Favours [control] }\end{array}$ & $\frac{1}{500}$ \\
\hline
\end{tabular}

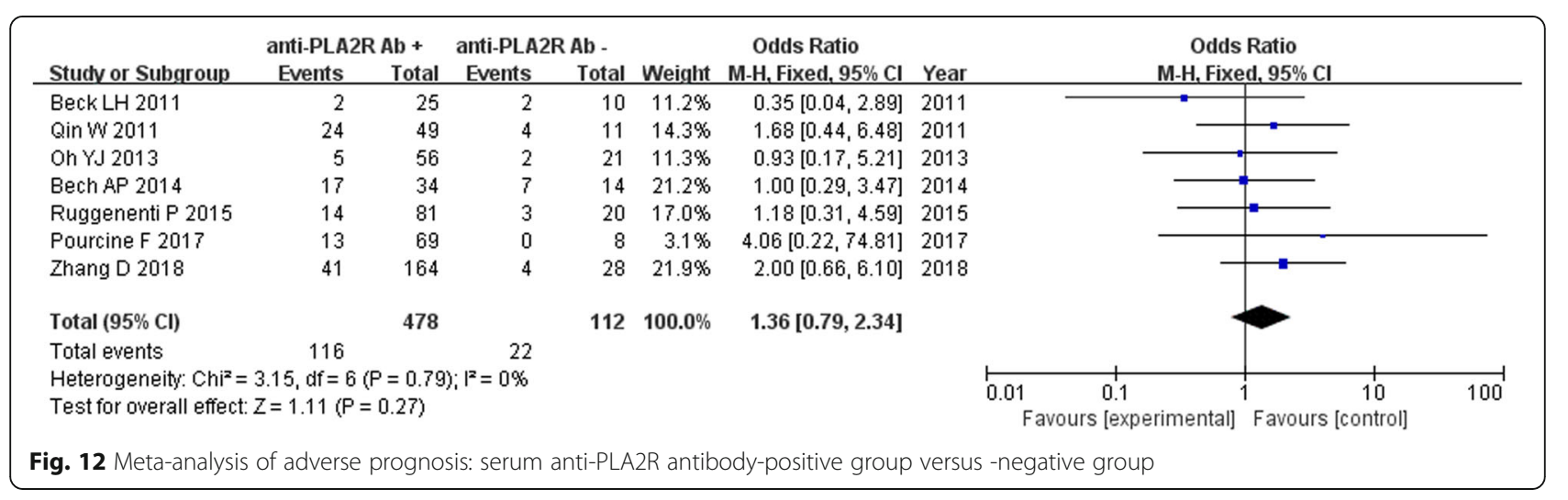

\begin{tabular}{|c|c|c|c|c|c|c|c|c|c|c|}
\hline Studv or Subgroup & \multicolumn{2}{|c|}{ 'High' titer } & \multicolumn{2}{|c|}{ 'Low' titer } & \multicolumn{2}{|c|}{$\begin{array}{c}\text { Odds Ratio } \\
\text { Weight } \\
\text { M-H, Fixed, } 95 \% \mathrm{Cl}\end{array}$} & \multicolumn{4}{|c|}{$\begin{array}{c}\text { Odds Ratio } \\
\text { M-H, Fixed, } 95 \% \mathrm{Cl}\end{array}$} \\
\hline Hofstra JM 2012 & 8 & 27 & 17 & 52 & $63.0 \%$ & $0.87[0.32,2.38]$ & 2012 & & & \\
\hline Timmermans SA 2015 & 16 & 44 & 5 & 29 & $29.5 \%$ & $2.74[0.87,8.60]$ & 2015 & & $=$ & \\
\hline Huang J 2017 & 6 & 25 & 1 & 14 & $7.5 \%$ & $4.11[0.44,38.23]$ & 2017 & & & \\
\hline Total $(95 \% \mathrm{Cl})$ & & 96 & & 95 & $100.0 \%$ & $1.66[0.84,3.29]$ & & & & \\
\hline Total events & 30 & & 23 & & & & & & & \\
\hline $\begin{array}{l}\text { Heterogeneity: } \mathrm{Chi}^{2}=2 \text {. } \\
\text { Test for overall effect: } Z\end{array}$ & $\begin{array}{l}7, d f=2(P \\
1.46(P=\end{array}$ & $\begin{array}{l}P=0.23 \\
0.14)\end{array}$ & 3); $I^{2}=33$ & & & & & Favours [experimental] & $\begin{array}{c}10 \\
\text { Favours [control] }\end{array}$ & 100 \\
\hline
\end{tabular}


Table 3 Analysis of publication bias

\begin{tabular}{|c|c|c|c|c|c|}
\hline \multirow[t]{2}{*}{ Factors } & & \multicolumn{3}{|c|}{ Egger's Test } & \multirow{2}{*}{$\begin{array}{l}\text { Begg's Test } \\
\operatorname{Pr}>|z|\end{array}$} \\
\hline & & $t$ & $P$ & $\% 95 \mathrm{Cl}$ & \\
\hline \multirow[t]{2}{*}{ Serum albumin } & serum & -2.36 & 0.056 & $-19.94,0.34$ & 0.035 \\
\hline & renal tissues & 0.07 & 0.958 & $-67.77,68.49$ & 1 \\
\hline \multirow[t]{2}{*}{ Age } & serum & -2.93 & 0.026 & $-1.93,-0.17$ & 1 \\
\hline & renal tissues & -0.25 & 0.843 & $-60.93,58.56$ & 1 \\
\hline Serum creatinine & serum & 0.66 & 0.539 & $-8.16,13.79$ & 0.386 \\
\hline eGFR & serum & 2.26 & 0.109 & $-0.50,2.94$ & 0.462 \\
\hline 24-hour urine protein & serum & -0.61 & 0.602 & $-13.2,9.91$ & 0.734 \\
\hline \multirow[t]{3}{*}{ Remission rate } & serum & -0.25 & 0.809 & $-3.26,2.63$ & 1 \\
\hline & renal tissues & -4.44 & 0.141 & $-24.65,11.88$ & 0.296 \\
\hline & higher or low titer group & -9.2 & 0.003 & $-9.94,-4.83$ & 0.027 \\
\hline \multirow[t]{2}{*}{ Adverse effects rate } & serum & -0.43 & 0.684 & $-3.29,2.34$ & 0.548 \\
\hline & higher or low titer group & 0.86 & 0.549 & $-30.83,35.29$ & 1 \\
\hline
\end{tabular}

$\mathrm{Cl}$ confidence interval, eGFR estimated glomerular filtration rate

to a large number of factors, no subgroup analysis was performed. Therefore, the source of heterogeneity among the included studies could not be assessed. (4) Due to the failure to obtain the original data of the included studies, what the specific PLA2R level and serum anti-PLA2R antibody titer was related to adverse prognosis of IMN were not indicated. Due to the failure to obtain the original data of the included studies, the specific PLA2R and serum anti-PLA2R antibody titer values were not indicated when introducing the relationship between PLA2R and its antibodies and IMN conditions. (5) There may be some potential factors in other studies that have not been included, resulting in biased selection in this meta-analysis. (6) We didn't register our review in PROSPERO.

Future research may be improved in the following respects: (1) Expanding the sample size, designing a multicenter cohort study, and extending the follow-up time as much as possible. (2) For further clarification of the relationship of serum anti-PLA2R antibody and PLA2R titer with clinical course of IMN, it is best to provide a specific titer range.

\section{Conclusion}

As compared to PLAR2, serum anti-PLAR2 antibody is more closely related with iMN disease progression. Compared with negative group, serum anti-PLA2 antibody -positive group had lower serum albumin, higher age, lower eGFR, and lower remission rate. In serum antiPLA2R antibody -positive group, the high-titer group had lower remission rate. The relationship of PLA2R expression in renal tissue with the clinical manifestations and prognosis of IMN patients cannot be ruled out.

\section{Abbreviations}

eGFR : Estimated glomerular filtration rate; ELISA: Enzyme-linked immunosorbent assay; ESRD: End stage renal disease; GBM: Glomerular basement membrane; IFA: Indirect immunofluorescence assay; IMN: Idiopathic membranous nephropathy; MD: Mean difference; MN: Membranous nephropathy; NOS: Newcastle-Ottawa scale; OR: Odds ratio; PLA2R: M-type phospholipase A2 receptors; RCTs: Randomized controlled trials; RR: Relative risk; SMD: Standardized mean difference; WB: Western blotting

\section{Acknowledgements}

Not applicable

\section{Authors' contributions}

Conception and design of the network meta-analysis: LZ, DD. Performance of the network meta-analysis: DD, TTF and LZ. Quality assessment of the network meta-analysis: TTF, LZ, LS and YYW. Analysis of study data: DD, TTF and LS. Writing of the paper: TTF, DD. All authors have read and approved the final version of the manuscript.

\section{Funding}

This study was supported by the Jilin Technology Department Natural Foundation of China (20160101122JC).

\section{Availability of data and materials}

The datasets used and analysed in the current study are available from the corresponding authors on reasonable request.

Ethics approval and consent to participate Not applicable.

Consent for publication

Not applicable

\section{Competing interests}

The authors declare that they have no competing interests.

\section{Author details}

'Department of Nephrology, First Hospital of Jilin University, 71 Xinmin Street, Changchun, Jilin 130021, People's Republic of China. ${ }^{2}$ Department of Nephrology, Binzhou People's Hospital, Binzhou, Shandong, People's Republic of China. ${ }^{3}$ Department of Nephrology, Jining No.1 People's Hospital, Jining, Shandong, People's Republic of China. 
Received: 20 June 2018 Accepted: 21 November 2019

Published online: 02 December 2019

\section{References}

1. Feng ZWS, Huang Y, Liang X, Shi W, Zhang B. A follow-up analysis of positron emission tomography/computed tomography in detecting hidden malignancies at the time of diagnosis of membranous nephropathy. Oncotarget. 2016;7(9):9645-51.

2. Ronco P, Debiec $\mathrm{H}$. Antigen identification in membranous nephropathy moves toward targeted monitoring and new therapy. J American Soc Nephrol: JASN. 2010;21(4):564-9.

3. Boskovic J, Arnold JN, Stilion R, Gordon S, Sim RB, Rivera-Calzada A, Wienke D, Isacke CM, Martinez-Pomares L, Llorca O. Structural model for the mannose receptor family uncovered by electron microscopy of Endo180 and the mannose receptor. J Biol Chem. 2006:281(13):8780-7.

4. Hoxha E, Harendza S, Zahner G, Panzer U, Steinmetz O, Fechner K, Helmchen U, Stahl RA. An immunofluorescence test for phospholipase-a (2)-receptor antibodies and its clinical usefulness in patients with membranous glomerulonephritis. Nephrology, dialysis, transplantation : official publication of the European Dialysis and Transplant Association European Renal Association. 2011;26(8):2526-32.

5. Ancian PLG, Mattéi MG, et al. the human 180-kDa receptor for secretory phospholipases A2. Molecular cloning, identification of a secreted soluble form, expression, and chromosomal localization. J Biol Chem. 1995;270(15):8963-70.

6. Beck LH Jr, Salant DJ. Membranous nephropathy: from models to man. J Clin Invest. 2014;124(6):2307-14.

7. Beck LH Jr, Bonegio RG, Lambeau G, Beck DM, Powell DW, Cummins TD, Klein JB, Salant DJ. M-type phospholipase A2 receptor as target antigen in idiopathic membranous nephropathy. N Engl J Med. 2009;361(1):11-21.

8. Beck LH Jr, Fervenza FC, Beck DM, Bonegio RG, Malik FA, Erickson SB, Cosio FG, Cattran DC, Salant DJ. Rituximab-induced depletion of anti-PLA2R autoantibodies predicts response in membranous nephropathy. JAmerican Soc Nephrol: JASN. 2011;22(8):1543-50.

9. Hoxha E, Thiele I, Zahner G, Panzer U, Harendza S, Stahl RA. Phospholipase A2 receptor autoantibodies and clinical outcome in patients with primary membranous nephropathy. J American Soc Nephrol: JASN. 2014;25(6):1357-66.

10. Wang $L$, Shang MH, Zhuge YF, Huang YX, Rong S, Tang ZH, Bao JF, Yu Q, Yuan WJ. Expression of renal PLA2R in patients with idiopathic membranous nephropathy and its relationship with the curative effect of immunotherapy. National Med J China. 2016;96(1):4-8.

11. Wang J, Xie Q, Sun Z, Xu N, Li Y, Wang L, Liu S, Xue J, Hao CM. Response to immunosuppressive therapy in PLA2R- associated and non-PLA2Rassociated idiopathic membranous nephropathy: a retrospective, multicenter cohort study. BMC Nephrol. 2017;18(1):227.

12. $\amalg J W, M H S, Y F Z, Y X H, M R, Z H T, J F B, Q Y, W J Y$ : expression of renal PLA2R in patients with idiopathic membranous nephropathy and its relationship with the curative effect of immunotherapy. National Med J China 2016(1):4-8

13. Liu H, Luo W, Gong S, Ding X. Detection and clinical significance of glomerular M-type phospholipase A2 receptor in patients with idiopathic membranous nephropathy. Intern Med J. 2016;46(11):1318-22.

14. Pourcine F, Dahan K, Mihout F, Cachanado M, Brocheriou I, Debiec H, Ronco P. Prognostic value of PLA2R autoimmunity detected by measurement of anti-PLA2R antibodies combined with detection of PLA2R antigen in membranous nephropathy: a single-Centre study over 14 years. PLoS One. 2017;12(3):e0173201

15. Ramachandran R, Kumar V, Kumar A, Yadav AK, Nada R, Kumar H, Kumar V, Rathi M, Kohli HS, Gupta KL, et al. PLA2R antibodies, glomerular PLA2R deposits and variations in PLA2R1 and HLA-DQA1 genes in primary membranous nephropathy in south Asians. Nephrology, dialysis, transplantation : official publication of the European Dialysis and Transplant Association - European Renal Association. 2016:31(9):1486-93.

16. Bech AP, Hofstra JM, Brenchley PE, Wetzels JF. Association of anti-PLA (2) $R$ antibodies with outcomes after immunosuppressive therapy in idiopathic membranous nephropathy. Clin J American Soc Nephrol: CJASN. 2014;9(8):1386-92.

17. Zhou GY, WI Z, Wu C, Zhuang ZQ, Wang XT, Zhao YY. the relationship between serum anti-M-type phospholipase $\mathrm{A} 2$ receptor antibody and manifestation or therapeutic response of membranous nephropathy. Chin J Gerontol. 2017;14:3574-7.
18. Qin W, Beck LH Jr, Zeng C, Chen Z, Li S, Zuo K, Salant DJ, Liu Z. Antiphospholipase A2 receptor antibody in membranous nephropathy. J American Soc Nephrol: JASN. 2011;22(6):1137-43.

19. Oh YJ, Yang SH, Kim DK, Kang SW, Kim YS. Autoantibodies against phospholipase A2 receptor in Korean patients with membranous nephropathy. PLoS One. 2013;8(4):e62151.

20. Kim YG, Choi YW, Kim SY, Moon JY, Ihm CG, Lee TW, Jeong KH, Yang SH, Kim YS, Oh YJ, et al. Anti-phospholipase A2 receptor antibody as prognostic Indicator in idiopathic membranous nephropathy. Am J Nephrol. 2015;42(3):250-7.

21. Ruggenenti $P$, Debiec $H$, Ruggiero B, Chianca A, Pelle T, Gaspari F, Suardi F, Gagliardini E, Orisio S, Benigni A, et al. Anti-phospholipase A2 receptor antibody titer predicts post-rituximab outcome of membranous nephropathy. J American Soc Nephrol : JASN. 2015;26(10):2545-58.

22. Timmermans SA, Abdul Hamid MA, Cohen Tervaert JW, Damoiseaux JG, van Paassen P, Limburg Renal R. Anti-PLA2R antibodies as a prognostic factor in PLA2R-related membranous nephropathy. Am J Nephrol. 2015;42(1):70-7.

23. Hofstra JM, Debiec H, Short CD, Pelle T, Kleta R, Mathieson PW, Ronco P, Brenchley PE, Wetzels JF. Antiphospholipase A2 receptor antibody titer and subclass in idiopathic membranous nephropathy. J American Soc Nephrol : JASN. 2012:23(10):1735-43.

24. Liang Y, Zhang XL, Zhu Q, Shao FM. Effect of adrenocorticosteroids combined with immunosuppressive agents on membranous nephropathy and its correlation with serum PLA2R antibody concentration. Guangdong Med J. 2017:38(12):1897-900

25. Huang J, Li JW, Liang M, Qin SG, Zhou SS, Fu JZ. Titer of serum antiphospholipase $\mathrm{A} 2$ receptor antibody predicts clinical outcome of idiopathic membranous nephropathy. Guangdong Med J. 2017;38(9):1348-53.

26. Zhang D, Zou J, Zhang C, Zhang W, Lin F, Jiang G. Clinical and histological features of phospholipase $\mathrm{A} 2$ receptor-associated and Thrombospondin type-I domain-containing 7A-associated idiopathic membranous nephropathy: a single center retrospective study from China. Med Sci Monit : Int Med J Exp Clin Res. 2018;24:5076-83.

27. Li Q, Zhang BR, He P, Qin XS, Zhao ZX, Zhang YZ, Wang YQ, Sun GP. Clinical application of serum PLA2R antibody detection inidiopathic membranous nephropathy. Chin J Pract Intern Med. 2018;38(12):63-66.

28. Chen A, Frank R, Vento S, Crosby V, Chandra M, Gauthier B, Valderrama $\mathrm{E}$, Trachtman $\mathrm{H}$. Idiopathic membranous nephropathy in pediatric patients: presentation, response to therapy, and long-term outcome. BMC Nephrol. 2007:8:11.

29. Pozdzik A, Brocheriou I, David C, Touzani F, Goujon JM, Wissing KM Membranous nephropathy and anti-Podocytes antibodies: implications for the diagnostic workup and disease management. Biomed Res Int. 2018; 2018:6281054

30. Sengupta U, Kumar V, Yadav AK, Marwaha N, Kohli HS, Sakhuja V, Jha V. Infusion of autologous bone marrow mononuclear cells leads to transient reduction in proteinuria in treatment refractory patients with idiopathic membranous nephropathy. BMC Nephrol. 2013;14:262.

31. Debiec HGV, Mougenot B, Decobert F, Haymann JP, Bensman A, Deschênes G, Ronco PM. Antenatal membranous glomerulonephritis due to antineutral endopeptidase antibodies. N Engl J Med. 2002;346(26):2053-60.

32. Dai $H$, Zhang $H, H e Y$. Diagnostic accuracy of PLA2R autoantibodies and glomerular staining for the differentiation of idiopathic and secondary membranous nephropathy: an updated meta-analysis. Sci Rep. 2015;5:8803.

33. Pang L, Zhang AM, Li HX, Du JL, Jiao LL, Duan N, Liu Y, Yu D. Serum anti-PLA2R antibody and glomerular PLA2R deposition in Chinese patients with membranous nephropathy: a cross-sectional study. Medicine. 2017:96(24):e7218.

34. Wei SY, Wang YX, Li JS, Zhao SL, Diao TT, Wang Y, Wang C, Qin Y, Cao Y, Wei $Q$, et al. Serum anti-PLA2R antibody predicts treatment outcome in idiopathic membranous nephropathy. Am J Nephrol. 2016;43(2):129-40.

35. Segarra-Medrano A, Jatem-Escalante E, Carnicer-Caceres C, Agraz-Pamplona I, Salcedo MT, Valtierra N, Ostos-Roldan E, Arredondo KV, Jaramillo J. Evolution of antibody titre against the M-type phospholipase A2 receptor and clinical response in idiopathic membranous nephropathy patients treated with tacrolimus. Nefrologia : Publicacion oficial de la Sociedad Espanola Nefrologia. 2014;34(4):491-7.

\section{Publisher's Note}

Springer Nature remains neutral with regard to jurisdictional claims in published maps and institutional affiliations. 